Disposal of Radioactive Waste

\title{
RW DISPOSAL IN RUSSIA: ANALYSIS OF KEY SAFETY ISSUES AND BOOSTING THEIR SOLUTION AT SCIENTIFIC AND TECHNICAL COUNCILS OF THE STATE CORPORATION "ROSATOM"
}

\author{
Utkin S. S. ${ }^{1}$, Dorogov V. I. ${ }^{1}$, Dorofeev A. N. ${ }^{2}$ \\ ${ }^{1}$ Nuclear Safety Institute of the Russian Academy of Sciences, Moscow, Russia \\ ${ }^{2}$ State Corporation "Rosatom", Moscow, Russia
}

Article received on April 21, 2020

The article summarizes the evaluations of key problems and boosted decision making on the safe RW disposal in Russia by scientific and technical councils of the State Corporation Rosatom in 2009-2020.

Keywords: radioactive waste, safety, criteria system, strategy for the development of a deep RW disposal facility, underground research laboratory, software package.

Currently, projects on design development and construction of RW disposal facilities are being implemented in Russia under the initiative on the establishment of the Unified State System for Radioactive Waste (RW) Management. The regulatory framework that evolved over the last decade, deployed managerial and material resources have largely contributed to these efforts [1]. Measures implemented under the development of the Unified State System for RW Management have demonstrated the need for the development of national approaches aimed at addressing the existing challenges in this area. This is the case of most important issues associated with the safety of RW disposal and their scientific and technical support: information and analytical base and the knowledge base required for research and fitted with complete and adequate sets of parameters relevant to the investigated processes, software and the opportunities for providing reliable forecasts on the evolution of specific facilities and materials, which is especially relevant and necessary in terms of assessing the long-term safety of RW deep disposal facilities.

RW disposal is a legislatively established prerogative of the National Operator for RW Management $[2,3]$. The tasks of safe RW disposal addressed by the National Operator are multi-subject in their nature and require collective efforts of the scientific community and experts from various fields. Such a knowledge platform is provided by relevant experts of the scientific and technical councils of the State Atomic Energy Corporation Rosatom. One of them, namely, the Scientific and Technical Council No. 10 Ecology and Radiation Safety deals primary with the problems associated with RW disposal safety, searching effective solutions and initiating their implementation. As a crosscutting matter, these problems are considered inter alia under the auspices of scientific and technical councils No. 5 on the Final Stage of the Nuclear Fuel Cycle, No. 1 Nuclear Power Units and Plants and No. 8 on the Advanced Technological Nuclear Power Platform. 
In addition to these four scientific and technical councils, RW disposal issues are regularly discussed under a task-specific section No. 1 Environmental and Radiation Safety of Long-Term Storage, Conservation and Disposal Facilities for Radioactive Waste established under the auspices of the Scientific and Technical Council No. 10.

This article summarizes the key challenges and the outcomes of a boosted decision-making on the development of a RW management system in Russia and the safety of RW disposal discussed at the meetings of the scientific and technical councils of the State Atomic Energy Corporation Rosatom in 2009-2020.

The following processes and addressed tasks were considered:

- study of problems and development of approaches aimed at establishing a system of criteria for RW identification and classification;

- establishment of a methodological basis and its scientific and technical support enabling practical efforts on the categorization of accumulated RW, identification of their amounts and conditions at relevant RW sites (primary registration);

- evaluation of optimal solutions and triggering the decision-making on their implementation under the stages suggested by deep RW disposal strategy;

- identification of effective approaches for URL $\mathrm{R} \& \mathrm{D}$ planning aimed at assessing the deep RW disposal safety;

- evaluation of approaches providing safety at existing RW disposal facilities;

- evaluation of approaches providing safety at newly developed RW disposal facilities;

- identification of areas and accelerated development of computational and software systems used for modeling and forecasting purposes under relevant long-term safety assessments of nuclear facilities.

The paper discusses the milestones providing solutions to each of the above tasks.

\section{Problem evaluation and development \\ of approaches aimed at establishing a system}

of RW identification and classification criteria

Success in the establishment of an effective RW management system in the Russian Federation [4, 5] providing the radiation safety of the population and the environment and compliance with international obligations under the Joint Convention on the Safety of Spent Fuel Management and on the Safety of Radioactive Waste Management [6, 7], on the one hand, cannot be achieved without scientifically sound and economically feasible criteria for RW identification and classification, and on the other hand, a system of criteria addressing a number of practical issues inherent to the development of the Unified State System for RW Management (USS RW) [8]. It's worth noting that these criteria should be established with a due account taken of three main factors: technical feasibility, economic feasibility and social acceptance. At the same time, relevant historical background should be considered taking into account volumes and characteristics of RW accumulated by the time of USS RW establishment and the geographical location of RW sites.

Approaches to the development of criteria for waste categorization as RW and their classification by disposal methods and disposal conditions were discussed at several meetings of Rosatom STCs. A case in point is the joint meeting of STC No. 5 and STC No. 10 held on February 29, 2012 [9] that involved an extensive evaluation of criteria proposed at the beginning of this meeting by the interested institutions and varying by the degree of their elaboration and completeness.

To make a balanced interagency decision, the scientific and technical councils had to develop a coherent vision on the differing provisions of the drafted proposal. Opinions expressed at the meeting and ample discussion allowed the STC to describe the ways for further evolution of RW concepts and the approaches to the establishment of criteria supporting the decision-making on waste assignment to RW category and recognizing it as falling under the scope of RW management requirements; RW categorization as retrievable subject to retrieval, conditioning and disposal at centralized disposal facilities (RWDF); RW categorization as non-retrievable subject to in-situ disposal; segregation of retrievable RW into classes for disposal purposes.

The basic structure of the documents was decided upon by the scientific and technical councils based on a harmonized core of the above vision. The numerical values of RW assignment criteria, in particular, for solid waste containing technogenic radionuclides, were determined based on approaches agreed upon in the drafts prepared by relevant institutions. As for liquid waste containing technogenic radionuclides, for which the approaches proposed by institution differed significantly, it was recommended to consider multiples of intervention levels (about 50-100) for all technogenic radionuclides, except for tritium. As for tritium-containing LRW, due to its specific properties, it was proposed to choose a single criterion based on which the waste could be assigned to LRW category. Regarding the criteria for RW categorization as non-retrievable, it 
was proposed to limit this category to waste generated as a result of defense activities and located at sites contaminated due to radiation or nuclear accidents.

As it comes to RW classification system for waste disposal purposes based on the period of its potential hazard, the joint meeting unequivocally recognized the compliance with the basic principle provided for in international recommendations.

The decisions made by the STC have formed a basis for interagency coordination of the draft provisions and subsequent approval of these criteria by the Government Resolution of the Russian Federation of October 19, 2012 No. 1069 On Criteria Used to Categorize Solid, Liquid and Gaseous Waste as Radioactive Waste, Criteria Used to Assign RW to Non-retrievable and Retrievable RW Categories, Classification Criteria for Retrievable RW (Government Resolution No. 1069) [10]. The Government Resolution played a key role in arranging an institutional basis for RW management activities and establishing relevant financial mechanism enabling the operation of the Unified State System for Radioactive Waste Management. Such important issues cannot be addressed solely through the adoption of some regulations, but also considering the feedback from their practical application. For this reason, approaches to the establishment of RW classification criteria and law enforcement practice concerning the requirements stipulated in provision of the Government Resolution No. 1069 were iteratively evaluated at STC meetings.

Thus, a number of urgent challenges associated with the implementation of practical activities was revealed at STC No. 10 of April 11, 2014 [12] based on the feedback from the implementation of requirements stipulated in the Government Resolution No. 1069 given relevant provisions of federal norms and rules in the field of atomic energy use, namely, NP-093-14 RW Acceptance Criteria for Disposal (NP-093-14) [11] and the experience of operating organizations (OJSC Rosenergoatom, FSUE NO RAO, etc.). Listed below are some of the revealed challenges: non-compliance of criteria used to categorize waste as RW with relevant provision of the Federal Law On Radioactive Waste Management and Amendments Introduced to Certain Legislative Acts of the Russian Federation of July 11, 2011 No. 190-FZ (Federal Law No. 190-FZ) providing opportunities for increasing the number of facilities holding RW; excessive expansion of RW inventory due to inclusion of materials containing short-lived radionuclides; assignment of RW containing radionuclides from group " $G$ " according to the radiation hazard level [13] to RW Class 3, even if its specific activity only slightly exceeds the minimum significant specific activity level, which does not correspond to the actual radiological hazard imposed by the waste.

The adopted decision specifically emphasized that the entire complex of identified problems associated with the enforcement of the Government Resolution No. 1069 had proved the reasonability of introducing certain amendments to it.

The relevance of introducing such amendments was acknowledged at a meeting of Section 1 of STC No. 10, recognized at the meeting of STC No. 10 of April 28, 2016 [14] in the course of discussions on the establishment of RW cementing complex at PA Mayak site. The urgency of this matter was stated repeatedly by FSUE PA Mayak during a joint meeting of STC No. 5 and STC No. 10 held on October 16, 2019 [15].

Conclusions and decisions of Rosatom's STC on the need of introducing certain amendments to the Government Resolution No. 1069 were further elaborated with relevant measures being introduced into the Action Plan on the implementation of the State Policy Fundamentals on Nuclear and Radiation Safety in the Russian Federation (Approved by Order of the Government of the Russian Federation of February 2, 2019 No. 139-r). Rostekhnadzor and the State Atomic Energy Corporation Rosatom became responsible for the preparation of the draft amendments, which was stipulated in relevant provision of the Government Resolution of the Russian Federation On Amendments Introduced to the Government Resolution of the Russian Federation of October 19, 2012 No. 1069 (Government Resolution on amendments PP-1069).

The following provisions of Government Resolution No. 1069 were recognized as requiring some amendment:

- criteria for RW categorization as non-retrievable RW;

- retrievable RW classification for disposal purposes.

In 2018-2019, corresponding SC Rosatom proposals on amending the above two key provisions were presented at the meetings of the coordination interagency commission for USS RW development and a special working group established for these purposes. However, interagency coordination on the proposed amendments has proved to be unsuccessful.

As the result of further concurrent efforts of two authorized departments, significant divergence in the goals and outlook on the amendments required to be introduced to the Government Resolution No. 1069 has manifested itself. This was mainly associated with different interpretation of reasonable safety limits, the approaches applied to evaluate the amount of resources required for the 
implementation of relevant measures, the scope of intentions and priorities in addressing the tasks.

In August 2019, a new area emerged under the development of proposals on amendments to the Government Resolution of the Russian Federation No. 1069, which was due to the introduction of fundamentally new, not previously considered proposals on criteria for solid waste categorization as RW and the classification criteria for retrievable RW to the draft paper developed by Rostekhnadzor. It was proposed to categorize industrial waste containing man-made radionuclides as RW up to the level of its release from radiation control. For objective reasons, this proposal was not accepted by SC Rosatom. The main reasons for that were as follows:

- USS RW infrastructure was not able to manage such a big waste inventory;

- measures have been taken, including the establishment of an interdepartmental working group to address the issues associated with the management of such waste;

- hazards imposed by such waste do not require the implementation of the entire range of measures provided for RW management;

- current environmental legislation governs activities in the field of industrial waste management, including industrial waste contaminated with technogenic radionuclides.

Discussions on the content of the Government Resolution on the introduced amendments PP-1069 were supported by a series of articles in scientific and technical journals $[16,17]$ presenting the arguments of the parties, as well as elaborating on possible setbacks associated with the introduction of a lower limit for RW categorization corresponding to the level of waste release from radiation control, which was proposed by the Federal State Budgetary Institution Scientific and Technical Center NRS and supported by Rostekhnadzor.

Some kind of a consensus on this matter between Rostekhnadzor and the State Atomic Energy Corporation Rosatom was expected to be reached during the meeting of STC No. 10 held on December 17 , 2019. However, only partial consensus could be reached at that time $[18,19]$.

In general, based on the discussion, a shared understanding has evolved between the State Atomic Energy Corporation Rosatom as a governing body in the field of RW management and Rostekhnadzor as a state nuclear regulatory on the need of abolishing non-safety-related restrictions on RW origin and location during the decision making on RW assignment to the non-retrievable RW category.

As for the other proposals discussed at this meeting and in the report of STC NRS, namely, those associated with criteria for waste assignment to the category of RW and retrievable RW classification, a clash of opinions expressed by STC members still persisted.

Most polar standpoints were expressed in the discussion on the management of industrial waste with a high content of technogenic radionuclides and relevant challenges: on this matter the stances of governing and regulatory bodies, as well as various organizations were still poles apart.

Rostekhnadzor's proposal on a significant expansion in the inventory of industrial waste being attributed to the RW category by reducing numerical values of RW assignment criteria up to a level corresponding to unrestricted use of solid materials, was judged by many experts as not being explicitly elaborated also due to the lack of necessary financial and economic evaluations.

Scientific and Technical Council No. 10 adopted some decisions on topical issues concerning the proposed amendment to the Government Resolution No. 1069.

Supported were the proposals presented by Rosatom's Project Office on USS RW Development in a series of open access publications and at meetings focused on practical applications and based on evaluations concerning relevant safety aspects and USS RW feasibility, in particular dealing with:

- abolishing restrictions on waste origin and location during decision making on waste assignment to the category of non-retrievable RW if these are not based on safety principles;

- expanding the list of retrievable RW classes and preserving the numerical values for the specific activities of individual technogenic radionuclides. These provisions are supposed to ensure the operation of the current financial model enabling the replenishment of a special reserve fund for RW disposal. The former list should also indicate the targeted use of the waste classes and provide standards allowing to identify specific RWDF considered suitable for the disposal of certain RW based on numerical values of the acceptance criteria established in accordance with federal norms and rules.

Scientific and Technical Council No. 10 acknowledged that consistent work is required to arrive with a coordinated interagency decision on all issues concerning the proposed updating of the Government Resolution No. 1069. Therefore, the STC recommended that SC Rosatom arranged for additional consultations with Rostekhnadzor to discuss the latest draft of the proposed amendments with the draft itself being discussed at a meeting of a coordination interagency commission for USS RW development. 
As regards the inclusion of industrial wastes with a high content of technogenic radionuclides into RW management domain, STC No. 10 has recognized that the following should to be taken into account in addressing this issue:

- additional/repeated initial registration of RW and RW sites;

- redistribution of federal budget funds to cover the management of the indicated industrial waste category;

- amendments to the exiting FNP system regulating RW management to establish requirements for the safe management of the industrial waste based on the actual hazards imposed by the waste. In general, STC has recognized the issue of industrial waste management with a high content of technogenic radionuclides as an urgent one requiring additional discussion with the involvement of a wide range of specialists and departments, considering economic, managerial and other factors. Therefore, this point was proposed to be put on the agenda of the Rosatom's STC No. 10 Ecology and Radiation Safety for 2020 providing for a substantive review of this issue with due consideration given to the best practices and plans of operating organizations concerning the management of such waste (Rosenergoatom Concern, JSC TVEL, FSUE PA Mayak, etc.).

\section{Establishment of a methodological base} and its scientific and technical support enabling practical efforts on the categorization of accumulated RW, identification of their amounts and conditions at relevant RW sites (initial registration)

Hands-on answers to the questions regarding the RW amount and the setup at RW sites were obtained during the initial inventory taking campaign [20], provided for by the USS RW.

A lot of preparatory work was been done by IBRAE RAS jointly with SC Rosatom, Rostekhnadzor, FMBA of Russia, Scientific and Research Center for Nuclear and Radiation Safety and nuclear enterprises. These efforts were implemented under the development of Scientific and Technical Guides for the Preparation of Materials Supporting the Decision-Making on RW Assignment to the Category of Non-retrievable RW [21-23] which was done paying due attention to the requirements of Russian regulatory framework, regulations and recommendations of international organizations in the field of atomic energy use, environmental protection, radiation safety and sanitary and epidemiological welfare. Techniques and approaches adopted in the Guide, as well as aspects of its pilot application to support the categorization of RW as non-retrievable RW located in the underground repositories of plant 235 and reservoir V-9 of FSUE PA Mayak, at a storage facility for of PA ECP (Sludge Collector storage facility) were evaluated and discussed at section No. 1 of STC No. 10 held on April 11, 2014 [12].

The approaches set forth in the Guide provided for the development of supporting justifications covering all criterial parameters, including waste origin and location stipulated in the Government Resolution No. 1069.

In keeping with the adopted approaches, to categorize RW as non-retrievable RW one should demonstrate that under most conservative estimates of collective effective radiation doses, risks of potential exposure, overall potential environmental damage and the costs associated with in-situ RW disposal are lower than those estimated under the option suggesting waste retrieval and its disposal.

The developed and adopted mechanism, adjusted according to the results of pilot projects, published scientific and technical Guide distributed to operating organizations, conducted trainings and consultations, as well as scientific and technical support of relevant activities implemented at SC "Rosatom" enterprises have prompted the initial inventory taking campaign that took place in 20132014. Its findings were acknowledged favorably on May 26, 2015 at the meeting of Section No. 1 of the STC No. 10 [24] and on July 8, 2015 at the meeting of STC No. 10 [25]. In particular, the scientific and technical councils have emphasized that:

- initial registration and inventory taking campaign contributed to the establishment of an information resource summarizing data on 2,100 facilities;

- operating organizations provided data by filling in relevant questionnaires on each RW site and interdepartmental commissions drafted acts of their initial registration approved by SC Rosatom.

RW retrieval and in-situ disposal scenarios were developed for each storage facility holding RW, which was done to demonstrate whether it was feasible to categorize the considered waste as nonretrievable RW and to identify the compliance with the criteria set forth in the Government Resolution. Thus, collective doses to personnel and the public, risks and costs associated with work execution were estimated for each scenario, including relevant estimates of damage caused to environmental objects. Supporting materials were prepared by operating organizations with the involvement of expert and scientific and technical support organizations (IBRAE RAS, SRC NRS, FMBA of Russia, FSUE "NO RAO").

Based on the acts, SC "Rosatom" compiled lists of long-term RW storage facilities, storage facilities 
for non-retrievable RW, facilities holding non-retrievable RW and RW disposal facilities, which were subsequently approved by the Government of the Russian Federation.

Establishment of specific timing and focus areas for further activities in relation to each facility is seen as a fundamental difference between the implemented RW initial registration and inventory taking campaign and all previously completed projects pursuing similar objectives.

\section{Evaluation of optimal solutions and triggering the decision-making on their staged implementation of the deep RW disposal strategy}

Developed disposal facility is considered as a key element of the infrastructure and a most challenging element providing the long-term safety in RW management. STC meetings were mainly focused on the development of a deep disposal facility (DDF) for RW Class 1 and 2.

For the first time ever, an unbiased evaluation of the project on the development of a DDF RW in the Nizhnekansk rock mass (hereinafter referred to as DDF NKM) was provided at the meeting of STC No. 10 held on September 5, 2013, which involved the consideration of the progress achieved in the development of designs and basic engineering solutions for the construction of a deep RW disposal facility in the bedrocks of the Nizhnekansk rock mass [26]. Proposals on DDF NKM design development were discussed at meetings engaging relevant organizations involving the reports made by design development organization ISC VNIPIpromtekhnologii which contributed to a common understanding of the general setup regarding the ongoing work and future plans.

An apparent trend has manifested itself, namely, the one associated with persistent clashes of opinions between those responsible for DDF design development and construction and those arguing for a reasonable guarantee of its safety. Reviewers from the Geophysical Center of the Russian Academy of Sciences, IGEM RAS, FBI STC NRS and IBRAE RAS, as well as a number of STC members who took part in the discussion of the reports were extremely concerned on some issues associated with general work program, $R \& D$ program to be implemented in the URL, compliance with IAEA recommendations, development of quantitative RW acceptance criteria for disposal.

Based on preliminary evaluation of the stateof-art in DDF development, opinions of reviewers expressed at the meetings, statements made by council members and experts during the discussions, STC concluded that the progress achieved by the design organization and the baseline design approaches only reveal the general areas associated with tasks at hand, but obviously are not sufficient to achieve the ultimate goal - DDF RW establishment. To address this goal even more extensive $R \& D s$ are required, the entire scope of which has been not provided for in available design solutions. To provide such an extensive list of R\&Ds the following priorities should be addressed:

- Development of a conceptual long-term work plan on DDF RW establishment, its commissioning, operation and closure;

- Development of a detailed program for URL construction and research;

- Arranging for scientific and technical support of relevant activities;

- Arranging for international cooperation on DDF RW development, including international safety assessment also covering the post-closure period.

Challenges associated with DDF RW development require consolidation of design development, research and managerial resources to much larger extent than it was provided for by the terms of references, decisions made and the powers of FSUE "NO RAO".

STC has recommended SC Rosatom to identify the measures that should be implemented to achieve the specified goals, including those provided for under the Federal Target Program for 2016-2025, to arrange for international cooperation and public outreach engaging its Public Council.

The Scientific and Technical Council has specifically emphasized that the international practice of countries that have already started DDF RW construction evidences the paramount importance given to the URL development and URL-based R\&Ds that allowed them to develop national data and knowledge bases providing subsequent confident design development and construction of DDF RW.

Critical evaluation of DDF RW design development plans provided at STC meeting in 2013 triggered a fundamentally deeper and more detailed consideration of challenges associated with RW Class 1 and 2, being largely focused on URL establishment, as well as development and implementation of a research program to validate safety-important design parameters considered essential for future effective URL performance.

Effective advancement in the development of balanced solutions to DDF challenges was made at STC meetings held in 2016.

Important recommendations on the refinement R\&D program developed by FSUE "NAO RAO" and the action plan for its implementation in URL NKM were presented on March 16, 2016 at STC No. 10 meeting of section No. 1 [27]. 
Discussion focused on the disposal concept held at STC No. 10 meeting on December 132016 constituted a key pillar to the decision-in-principle on DDF RW establishment [28]. During the discussion, a number of issues requiring additional consideration were acknowledged, namely: comprehensive hydrogeochemical studies with additional well cluster drilling had to be performed to investigate ground water flows in the bedrocks; inventory of waste pending disposal had to be clarified (waste composition, type and volume); the time frame to be accounted for in the safety case had to be specified; methodological and regulatory support had to be provided to validate measured safety-important indicators, bedrock properties and the processes occurring in it; the order in which the problems were to be solved had to be explicitly described, as well as the scope of relevant challenges and the interdependency of different activities.

Strenuous efforts on preliminary study of safetyimportant issues associated with the geological disposal of RW, ways of addressing future problems and their discussion at STCs resulted in an essential conclusion suggesting that a single strategic document enabling coordination and optimization of activities carried out by various design and scientific organizations should be developed, as well as detailed specific action plans, a basic tool for continuous iteration of the results achieved and their expert assessment. All these considerations resulted in the Strategic Master Plan Supporting Long-Term Safety Assessments and Safety Case Development for DDF RW Intended for RW Class 1 and 2 Disposal in the Nizhnekansk rock Mass (hereinafter SMP NKM), including the disposal concept, detailed discussion of preparatory work addressing the priority tasks, requirements to the source data and the results associated with specific implemented activities and stages.

SMP NKM is not only focused on URL NKM establishment and operation. Its results should provide basic answers to the questions raised by public and safety regulatory authorities on the safety of Class 1 and 2 RW disposal at the proposed site. Draft SMP NKM provisions were issued in 2016 [29].

As it comes to the design solutions proposed for URL and DDF RW construction, STC stated that these should be considered at a joint meeting of STC No. 5 and STC No. 10 to provide a fully-fledged study of the issue and a detailed evaluation of the basic design and engineering solutions. This proposal was implemented which has necessitated enormous preparatory efforts.

Following a series of preliminary discussions with FSUE NAO RAO, key milestones and focus areas for DDR RW and URL establishment were identified at a joint meeting of STC on Basic Design and Engineering Solutions for URL and DDF RW (Nizhnekansk Rock Mass) held on October 27, 2017 [30]. Scientific and technical councils analyzed and discussed the Strategy for the Development of a Deep Radioactive Waste Disposal Facility (hereinafter referred to as the Strategy), envisaged basic design and engineering solutions for the coming years, and the Strategic Master Plan Supporting Long-Term Safety Assessments and Safety Case Development for DDF RW Intended for RW Class 1 and 2 disposal in the Nizhnekansk rock mass.

Presentations, expert statements and views expressed at the meeting repeatedly noted that adequate profoundness and reliability of data presented in the safety case and covering extensive time periods should provide an essential contribution to addressing the challenge of HLW disposal. International deep disposal practice demonstrates that DDF RW development is advisable to be started with URL construction enabling detailed geological studies of the proposed site structure and the interactions between structural elements of the facility and the bedrocks, testing of proposed engineering solutions to be applied during DDF RW construction and operation and acquisition of necessary reliable data. It was emphasized that practical implementation of any decisions should be based on detailed knowledge and account for public acceptance.

Scientific and technical councils have acknowledged that the tasks being addressed are interdisciplinary by their nature and require the engagement of a wide range of experts, a balanced approach to decision-making and their adjustment depending on the results obtained. These tasks could be addressed based on generalized knowledge and experience gained in various areas of modern science and technologies.

On the whole, the discussion revealed a consensus on such fundamental issues as the need for a phased DDF RW construction strategy, complete and iterative validation of all decisions made, the goals of URL establishment and time frames for research conducted therein, the possibility of conducting reviews of certain important decisions and its binding nature including public reviews. All these aspects contributed to a favorable position on the proposed iterative adjustment of the developed designs, construction tactics and methods for $\mathrm{R} \& D$ s planning which was reflected in relevant decision of the STC.

At the same time, representatives of the state safety regulatory body shared their balanced attitude being focused solely on the safety assessment and safety demonstration. 
STC No. 5 and STC No. 10 have generally approved the draft Strategy and the SMP NMP and have recommended their interagency coordination and subsequent approval following the consideration of the expressed remarks.

Decision made by the scientific and technical councils suggested that URL and a Research \& Demonstration Center would be considered by the National Operator as fully-fledged phases under the DDF RW development project. SC Rosatom was recommended to consider the establishment of governing bodies responsible for project implementation; to introduce amendments to the federal target program Nuclear and Radiation Safety in 2016-2030 (hereinafter referred to as FTP NRS-2) to decompose the focus area on URL development into relevant types of activities; to specify the procedure for the establishment of a scientific coordinator under the URL and DDF RW development projects represented by IBRAE RAS, to approve the chief designer and chief engineering constructor under DDF RW development project, to consider whether it's needed to expand the list of chief specialists under FSUE NO RAO structure.

The discussion was concluded by a statement of the Member of Russian Academy of Sciences L. A. Bolshov who expressed his conviction that the only correct and honest way to interact with public is to abandon the idea of RW Class 1 and 2 disposal at the considered site if URL research performed to demonstrate the long-term safety of DDF RW do not yield positive results. In this case, as in other countries, it will be necessary to initiate another siting process for the DDF RW.

It should be noted that on March 28, 2018, the Strategy for the Development of a Deep Radioactive Waste Disposal Facility was approved by the Director General of the State Atomic Energy Corporation Rosatom A. E. Likhachev [31].

The decision made by the scientific and technical councils providing for regularly review of the progress achieved in URL and DDF RW development has been consistently implemented, and already in 2018, this matter has been already considered twice at Section No. 1 of the STC No. 10.

Proposals on the content and coordination of activities performed to implement the Strategy were put on the agenda of a meeting held on July 9 , 2018 [32]. It has been acknowledged that SMP NKM project enabled the development of an $R \& D$ program presenting a harmonized and complete list of time-based and interrelated design, research and development tasks. Starting from 2019, it was recommended that SC Rosatom put in place necessary financial provisions to cover the costs associated with addressing the key tasks specified under phase
No. 1 of the Strategy, namely Preliminary Efforts on URL establishment that was planned to be implemented in no more than 5 years (2017-2021). It was emphasized that a delayed funding suggesting that some R\&Ds stated under the program would be launched later than 2019, in particular, the R\&Ds focused on the identification of subsoil parameters under an undisturbed state, entails the risk of delaying the start of the pre-construction phase.

A wide range of research goals and objectives requires the closest possible interaction between scientific organizations and FSUE NO RAO as a responsible subsoil user and a customer of URL construction. Provisions of STC decision acknowledge the active engagement of the Russian Academy of Sciences, namely, IBRAE RAS, IGEM RAS, IHEP RAS, St.Petersburg Branch of the Institute of Geoecology RAS, Geophysical Center of RAS. Along the progress achieved in the implementation of the Strategy, the list of scientific organizations will tend to become more and more extensive. Centralized information and analytical resource PULSE may serve a knowledge base platform and an information basis providing interaction between different scientific organizations. Given the structure of the tasks and the expected period of intensive (2019-2030) calculations supporting DDF RW safety assessments, it was decided to arrange for the development of a new computational cluster.

Considerable attention has been paid to the fact that research results may be recognized by the scientific community and general public only provided maximum transparence and open access to scientific papers in peer-reviewed Russian and international publications. Moreover, the research results and DDF RW safety case materials can get international recognition only provided active and long-term engagement of Russian experts in international working groups, commissions, expert communities, etc. (IAEA, OECD Nuclear Energy Agency, etc.) and presentation of these results in top-tier scientific journals.

It was recognized that the accomplished efforts have set the scene for the implementation of the decision made at the joint meeting of STC No. 5 and STC No. 10 of SC Rosatom held on October 27, 2017 on additional funding to implement measure 2.1, namely, Construction of a Final Disposal Facility (deep disposal facility) for Radioactive Waste of Class 1 and 2 (Krasnoyarsk Territory, Nizhnekansk Rock Mass), First Section under FTP NRS-2 given corresponding expenditure items on an annual basis until 2025.

Proposed URL layout was discussed at the second meeting of Section No. 1 of STC No. 10 held on October 10, 2018, focused on the completeness of URL 
experiments [33]. The layout will be discussed in a below section dealing with approaches enabling R\&D planning.

\section{Identification of effective approaches}

for planning R\&Ds in the underground research laboratory aimed at assessing the safety of a deep RW disposal facility

As noted above, in demonstrating the safety of DDF RW the scientific and technical council attaches primary importance to R\&Ds performed in URL. Plans for such R\&Ds in terms of their scientific and managerial structure are discussed in the Research Program for the Underground Research Laboratory in the Nizhnekansk Rock Mass developed by FSUE "NO RAO", which was discussed by a number of leading scientific and design organizations of SC Rosatom, Rostekhnadzor and RAS, and the Action Plan for the Implementation of a Research Program in the Underground Research Laboratory in the Nizhnekansk Rock Mass to Validate SafetyImportant Design Parameters for the Underground RW Disposal for RW Class 1 and 2 providing for the R\&Ds to be implemented simultaneously with URL construction. The latter was discussed at a meeting of Section No. 1 of Rosatom's STC No. 10 held on March 16, 2016 [27].

It was recognized that the debaters had proposed a large number of activities and measures, with some of them being related to the fundamentals of the disposal concept.

A decision was made at the section recommending FSUE "NO RAO" to consider these proposals to finalize the plan.

In 2016, during the compilation of the activities it was considered feasible to expand it, providing, in particular, the development of a draft strategic master plan supporting long-term safety assessments and justifications (SMP).

By 2016, some specific activities have been identified as the priority ones by the STC, in particular, to build a structural model of the NKM fractured domain, to simulate the transfer of radionuclides with groundwater flows in a fractured rock mass, to build thermodynamic, and geomechanical models, to study the protective properties of natural and engineered DDF RW barriers, to provide a wellfounded list of parameters describing the scenarios associated with natural and technogenic impacts given the setup at the proposed site, to summarize the results of previous studies (including international ones) given their application within the safety case developed for the DDF RW.

As mentioned earlier, another substantive discussion focused on the content of the experiments planned in the URL and providing necessary data for DDF RW long-term safety assessments took place on October 10, 2018 at the meeting of Section No. 1 of STC No. 10 [33]. Its presentations were devoted to the composition of the planned R\&Ds, evaluation of international and national experience, the goals and expected results of the experiments, main conditions for their implementation.

The possibility of using radioactive substances during the URL research was also discussed at the meeting.

By the end of the meeting, STC acknowledged that public obligations of FSUE "NO RAO" ruling out the presence of radioactive substances at the facility impede the use of radioisotope methods to study the geological environment given the effective legislative provisions and have nothing to do with actual RW disposal.

Based on the compiled R\&D list, STC concluded that the general research program contains about 150 interrelated design, research and development tasks with some 50 of them being focused on pilot URL installations.

For further elaboration of this work package, proposals on the composition of the planned experiments supporting DDF RW safety assessments both at operational and post-closure stages were developed. It includes about 40 experiments covering 9 focus areas. These experiments should be launched under the first and second phases of the Strategy implementation including the mining stage. Requirements for their implementation should be set forth in the provisions of the URL upgrading designs. Some 10 more experiments devoted to RW emplacement technologies will be conducted no earlier than at the third phase of the Strategy implementation. URL research program and the planned experiments were subsequently discussed at a joint meeting of STC No. 5 and No. 10 held on October 16, 2019: discussions of URL NKM layout were supported by the estimates on the scope of research activities required to demonstrate the long-term safety of DDF RW [15].

A comprehensive research program has been finalized and adopted under the first phase of the approved Strategy to assess the long-term safety of RW disposal and to optimize SMP NKM provisions for the planning period until 2030. The following measures were specified as the priority ones (2019-2021):

- pre-design feasibility study on URL layout upgrading specifying the list of research facilities, their locations, research equipment, systems providing their performance;

- deployment of integrated long-term observation systems to monitor the main safety-important processes; 
- geological exploration, including the identification of structural disturbances and undisturbed rock units, specification of the tectonic setup within the DDF RW siting area and forecasts of its further evolution, refinement of groundwater characteristics;

- addressing the issues associated with the outfitting of experimental units, methodological support of activities performed at the site and in laboratories, materials and calculation tools.

Accounting for engineering and design documentation required to perform research during URL construction was stipulated as an important task that had to be addressed in the nearest future (late 2019 - early 2020). The developed Program for the Scientific Support of Mining Operations and its findings at phases I and II of the Strategy implementation are viewed to become a key element of URL licensing process and its international review.

STC proposed the following list of activities to be accounted for as top-priority ones during the adjustment of design documentation:

A) during URL construction:

- in-depth geological surveys under each excavation cycle allowing to map the fractures, describe the geology of exposed areas, perform prompt hydrogeological surveys, etc.;

- purpose interval hydrogeological and geomechanical surveys focused on identified challenging areas within the rock mass;

- construction and operation of experimental units fitted within mine shafts.

B) during URL operation:

- thermomechanical, geomechanical, hydrogeological, microbiological, geochemical and barrier experiments;

- operation of observation network and experimental nodes fitted within vertical shafts;

- testing of engineering solutions providing RW emplacement and installation of backfilling materials to seal the excavations.

Relevant activities should be implemented under specifically developed design documentation on URL operation during its expansion. It's considered advisable to start the development of new design provisions no later than 2022 .

\section{Evaluation of approaches providing safety at existing RW disposal facilities}

At present time, there are four operating LLW and ILW disposal facilities, namely: three facilities for deep LRW disposal (hereinafter, DDF LRW) operated by SC Rosatom (FSUE MCC, JSC SCC, ISC SSC RF RIAR) providing for LRW disposal via its injection into deep reservoir beds and the first section of a near-surface SRW disposal facility at UECC site.

All of the LRW disposal facilities, Pilot-Industrial Disposal Site (Ulyanovsk Region, Dimitrovgrad), Disposal sites 18 and 18a (Tomsk Region, Seversk), Severniy Disposal site (Krasnoyarsk Territory, Zheleznogorsk) being under federal ownership are now operated by FSUE NO RAO.

In 2013, IAEA pear-review mission was held to evaluate the Russian deep-well LRW injection practice. Its findings revealed some main limitations associated with the approach applied to demonstrate the long-term safety of DDF LRW due to which one could not suggest a full compliance of the Russian safety demonstration practice with the requirements of IAEA SSR-5.

Based on its findings, DDF LRW safety-important issues were evaluated at the meeting of STC No. 10 held on April 17, 2014 [34]. Discussed were the proposals presented by FSUE "NO RAO" considering a program of computational and experimental DDF LRW studies (hereinafter referred to as the Program) addressing the expressed remarks and supporting the development of a detailed program for DDF LRW closure. The latter one was supposed to include the following key areas: conceptual and mathematical description of DDF LRW evolution; materials and structures that will be applied at the closure stage; regulatory aspects associated with DDF LRW closure.

As it comes to the progress achieved in certain areas indicated under the Program, in particular, noted were the discrepancies in the requirements on the mipmapping level of the developed models and interactions between the considered processes; the key role of radiation-induced thermal effects and the importance of microbiological research; accumulated experience of IBRAE RAS in the development of a modern three-dimensional geomigration geofiltration model of the Severniy disposal site and the need for well-targeted arrangement of similar type research at different disposal sites and applying already available and purpose-developed models; the need for continued elaboration and expansion of a safety-important FEPs list; discrepancies in the significance of the parameters measured under experimental studies for the safety demonstration findings.

STC No. 10 has also recommended that the refined Program should be supported by computational and experimental DDF LRW studies to demonstrate the safety and feasibility of a detailed repository closure concept and to address the flaws noted by IAEA peer-review mission.

Over 25 research projects have been implemented in this area, a number of experimental research 
programs was developed. A number of documents supporting the long-term safety demonstration in accordance with international standards is being developed, amendments are being introduced to relevant provisions of DDF LRW closure concept with some particular technologies enabling wells decommissioning being worked out. The supplemented program has been recommended for approval.

\section{Evaluation of approaches providing safety of developed RW disposal facilities}

Compliance of the developed disposal facility for RW class 3 and 4 (on the basis of SRW storage facility at FSUE Radon site) with already available similar facilities, including those constructed abroad, in terms of their performance and environmental safety was discussed at a meeting of Section No. 1 held on May 25, 2015 [35].

A detailed discussion allowed to recognize the developed design documentation for RW class 3 and 4 disposal facility proposed for construction at FSUE Radon site as generally complying with both IAEA recommendations and similar international designs, in particular, Center De L'Aube (ANDRA) in France, El Cabril in Spain (LILW, ENRESA), Dessel in Belgium, Dounreay in the UK. It was recognized that these materials can support the long-term post-operational safety case developed at the stages of Environmental Impact Assessment (EIA) and Pre-investment Feasibility Study that would comply with the requirements and recommendations of modern legal and regulatory framework and international approaches.

Meeting held on April 12, 2019 by Section No. 1 of STC No. 10 was devoted to challenges associated with the design development ensuring the longterm safety demonstration for near-surface disposal facilities intended for SRW Class 3 and 4 [36].

Timely commissioning of near-surface disposal facilities for RW class 3 and 4 (hereinafter NSDF) is considered as a top-priority task for USS RW development with the initial radionuclide composition of the RW being viewed as a most important parameter affecting NSDF long-term safety. The lack of data on the radionuclide composition relevant for the long-term safety of NSDF for RW class 3 and 4 results in the need of considering most conservative safety analysis scenarios implying the use of maximum radionuclide specific activities set forth in the Government Resolution No. 1069. Such an approach seems to be acceptable in terms of safety justification, but can result in excessive costs. Furthermore, its effect is greatly enhanced due to the commitment of design organizations on the use of common engineering solutions and the imperfections of the retrievable RW classification system set forth under the Government Resolution No. 1069.

Based on the discussion, Section No. 1 of the STC No. 10 decided:

1. To prioritize the task of developing a consolidated industry-wide stance on introducing amendments to the Government Resolution No. 1069.

2. RW classification criteria for disposal purposes shall provide for:

- their establishment based on preliminary (framework) long-term safety evaluation and more flexible consideration of individual radionuclide characteristics, such as: half-life, radiotoxicity, migration ability;

- greater flexibility (partial or complete exclusion, setting ranges, use of descriptive language, etc.) with respect to the establishment of boundary specific activities for radionuclides;

- the need for further elaboration of requirements concerning NSDF for certain RW types (graphite, spent sealed radionuclide sources (SSR), very lowlevel radioactive waste (VLLW)). It was recommended to FSUE NO RAO and main RW generators:

- to analyze the practice of RW transfer for disposal and possible changes in it after the amendment of Government Resolution No. 1069;

- to develop a strategy for RW Class 3 and 4 disposal taking into account the introduced amendments to the Government Resolution No.1069, more clearly defined data on RW disposal volumes, RW radionuclide composition and the results of longterm and operational safety assessment under various scenarios.

It should be noted that at present time, SC Rosatom's Project Office for USS RW Development has initiated the development of a safety guide providing for some recommendations on the list of radionuclides, the composition of which should be monitored and reflected in RW packaging passports.

\section{Identification of areas and accelerated development of computational and software systems used for modeling and forecasting purposes under long-term safety assessments of nuclear facilities}

Software tools are viewed as a must during the research performed to demonstrate RW disposal safety. At the same time, in many cases, foreign software products are involved addressing these problems on a non-alternative basis. Their use is fraught with obvious risks associated with the dependence on the developer and the loss of national competence. In addition, it's often considered impossible to use foreign codes in the development of 
purpose-specific models of complex facilities, such as DDF RW NKM.

The state-of-art and strategic needs of computer code systems needed to demonstrate radiation and environmental safety of nuclear legacy and RW disposal facilities were considered at a meeting of STC No. 10 held on October 24, 2018 (a follow up one to the meeting of STC No. 10 of October 29, 2015 [37], which recommended two software systems, namely, NIMFA (FSUE RFNC VNIIEF) and GeRa (IBRAE RAS and INM RAS) to be considered as relevant industry-specific codes addressing geomigration and geofiltration modeling problems). Priority tasks in this area were stated, namely, those concerning the upgrading of software tools to a level considered adequate to enable their submission for an expert review and providing reliable experimental data suitable for software verification [38].

Views expressed at this meeting suggest that the development and implementation of national software tools is currently considered as a strategic task for the development of import independent Russian technologies. Moreover, the development of complex three-dimensional computational models and algorithms, as well as evaluation of calculation errors using such models and algorithms, requires significant efforts for their verification and validation. Therefore, verification (validation) of software products is believed to be of a particular relevance.

STC decision emphasized that the main focus areas recommended by STC No. 10 of March 12, 2015 providing for the development of software and mathematical models are being successfully addressed. In particular, the following codes are being developed:

- FENIA (heat release and stress-strain state modeling);

- Destruct (methodology and analysis of processes occurring within the system of engineered safety barriers);

- GeRa v.2 (modeling of processes occurring in the geological environment);

- CORIDA (assessment of RW characteristics and calculation of doses from external exposure);

- MOUSE (sensitivity and uncertainty assessments).

Software and mathematical models' development should result in a national safety justification methodology.

Efforts addressing the development of a software system designed for comprehensive safety demonstration of nuclear legacy and RW disposal facilities got positive recognition. It was recommended to provide for the following arrangements: technical specifications for operations should be amended to introduce a required examination of computer software products and arrange for additional measures ensuring the adequacy of their maturity level for such examinations which has to be done until 2025; requirements on the identification and formatting reliable data for verification (validation) of software should be specified within the terms of reference for planned comprehensive engineering and radiation survey.

\section{Conclusion}

The paper evaluates the activities implemented by scientific and technical councils of the State Atomic Energy Corporation Rosatom on addressing problems and accelerating the decision-making on RW disposal safety in Russia in 2009-2020.

The paper provides a comprehensive discussion of key processes related to RW disposal safety, namely, the dynamics of relevant managerial efforts implemented by scientific and technical councils of SC Rosatom, thus, providing an in-depth understanding of the thoroughness and validity involved in the decision making on the best approaches, as well as initiatives providing accelerated and more efficient decision-making on the issues relevant for the final RW management stage.

\section{References}

1. Dorofeev A. N. O khode rabot po razvitiyu normativno-pravovoy bazy $\mathrm{v}$ oblasti obrashcheniya $s$ radioaktivnymi otkhodami [On the progress in the development of a regulatory framework in the field of radioactive waste management]. Radioaktivnyye otkhody - Radioactive waste, 2019, no. 3 (8), pp. 6-13.

2. Federalnyy zakon ot 11.07 .2011 no. $190-\mathrm{FZ}$ «Ob obrashchenii s radioaktivnymi otkhodami i o vnesenii izmeneniy v otdel'nyye zakonodatel'nyye akty Rossiyskoy Federatsii» [Federal Law of July 11, 2011 no. 190-FZ "On the Management of Radioactive Waste and on Introducing Amendments to Certain Legislative Acts of the Russian Federation"].

3. Rasporyazheniye Pravitel'stva Rossiyskoy Federatsii ot 20.03.2012 no. 384-r «Ob opredelenii natsional'nogo operatora po obrashcheniyu s radioaktivnymi otkhodami» [Order of the Government of the Russian Federation of March 20, 2012 no. 384-r "On the establishment of a national operator for radioactive waste management"].

4. Sostoyaniye i perspektivy razvitiya sistemy obrashcheniya S RAO: Resheniye tematicheskoy sektsii no. 10 «Yadernaya i radiatsionnaya bezopasnost'» NTS Goskorporatsii «Rosatom» ot 17.06.2009 [Current state and prospects for the development of radioactive waste management system: Decision of thematic section no. 10 "Nuclear and Radiation 
Safety" made by STC of the State Corporation "Rosatom" on June 17, 2009].

5. O programme sozdaniya yedinoy gosudarstvennoy sistemy obrashcheniya s RAO: Resheniye tematicheskoy sektsii no. 10 «Yadernaya i radiatsionnaya bezopasnost'» NTS Goskorporatsii «Rosatom» ot 03.06.2010 [On the program for the development of a unified state system for radioactive waste management: Decision of thematic section no. 10 "Nuclear and Radiation Safety" made by STC of the State Atomic Energy Corporation Rosatom on June 6, 2010].

6. Kryukov O. V., Khaperskaya A. V., Dorofeev A. N., Ferapontov A. V., Kudryavtsev E. G., Linge I. I., Utkin S. S., Dorogov V. I., Sharafutdinov R. B., Ponizov A. V., Vasilishin A. L. Vypolneniye obyazatel'stv Rossii v ramkakh Ob"yedinennoy konventsii o bezopasnosti obrashcheniya s otrabotavshim toplivom i o bezopasnosti obrashcheniya s radioaktivnymi otkhodami [Implementing obligations of Russia under the Joint Convention on the Safety of Spent Fuel Management and the Safety of Radioactive Waste Management]. Radioaktivnyye otkhody - Radioactive Waste, 2019, no. 1 (6), pp. 25-36.

7. Linge I. I., Dorogov V. I., Sharafutdinov R. B., Nepeypivo M. A., Khaperskaya A. V. Ob opyte predstavleniya Natsional'nykh dokladov Rossiyskoy Federatsii po vypolneniyu obyazatel'stv v ramkakh Ob"yedinennoy konventsii [On the experience of submitting National Reports of the Russian Federation on the implementation of obligations arising from the Joint Convention]. Yadernaya i radiatsionnaya bezopasnost' - Nuclear and Radiation Safety, 2016, no. 1 (79), pp. 18-27.

8. Postanovleniye Pravitel'stva Rossiyskoy Federatsii ot 19.10.2012 g. no.1185 «Ob opredelenii poryadka i srokov sozdaniya YEGS RAO» [Resolution of the Government of the Russian Federation of October 19, 2012 no. 1185 "On the established procedure and timeframes for USS RW development"].

9. O voprosakh kriteriyev i klassifikatsii RAO: Resheniye sovmestnogo zasedaniya ot 29.02.2012 NTS no. 5 «Zamykayushchaya stadiya yadernogo toplivnogo tsikla» i NTS no. 10 «Ekologicheskaya, yadernaya i radiatsionnaya bezopasnost'» Goskorporatsii [On criteria and radioactive waste classification matters: Decision of a joint meeting held on February 29, 2012 by STC no. 5 "Final stage of nuclear fuel cycle" and STC no. 10 "Ecological, nuclear and radiation safety" of the State Atomic Energy Corporation ROSATOM. - Approved by the chairman of STC no. 5, Member of RAS Myasoedov B. F. and the chairman of the STC no. 10, Corr. Member of RAS Bolshov L. A.].

10. Postanovleniye Pravitel'stva Rossiyskoy Federatsii ot 19 noyabrya 2012 g. no.1069 «O kriteriyakh otneseniya tverdykh, zhidkikh i gazoobraznykh otkhodov $\mathrm{k}$ radioaktivnym otkhodam, kriteriyakh otneseniya RAO k osobym radioaktivnym otkhodam i $\mathrm{k}$ udalyayemym radioaktivnym otkhodam i kriteriyakh klassifikatsii udalyayemykh RAO» [Resolution of the Government of the Russian Federation of November 19, 2012 no. 1069 "On criteria for classifying solid, liquid and gaseous waste as radioactive waste, criteria for RW assignment to the category of special (non-retrievable) and retrievable radioactive waste and classification criteria for retrievable RW"].

11. Federal'nyye normy i pravila v oblasti ispol'zovaniya atomnoy energii. "Kriterii priyemlemosti radioaktivnykh otkhodov dlya zakhoroneniya» (NP-093-14): utverzhdeny prikazom Federal'noy sluzhby po ekologicheskomu, tekhnologicheskomu i atomnomu nadzoru ot 15.12.2014 no. 572. [Federal norms and rules in the field of atomic energy use. "Radioactive waste acceptance criteria for disposal" (NP-093-14): approved by the order of the Federal Service for Ecological, Technological and Atomic Supervision of December 15, 2014 no. 572].

12. Prakticheskoye primeneniye predpriyatiyami postanovleniya Pravitel'stva Rossiyskoy Federatsii ot 19 oktyabrya 2012 g. no. 1069. Razrabotka obosnovaniy na osnove «Nauchno-tekhnicheskogo posobiya po podgotovke obosnovyvayushchikh materialov dlya prinyatiya resheniya ob otnesenii RAO k osobym RAO: Resheniye sektsii no. 1 «Ekologicheskaya i radiatsionnaya bezopasnost' punktov dolgovremennogo khraneniya, konservatsii i zakhoroneniya RAO» NTS no. 10 Goskorporatsii «Rosatom» ot 11.04.2014. [Government Resolution of the Russian Federation no. 1069 of October 19, 2012: Practical application by enterprises. Development of justifications based on provisions of "Scientific and technical manual on the development of materials supporting the decision-making on radioactive waste assignment to the non-retrievable (special) radioactive waste category: Decision of section no. 1 "Ecological and radiation safety of long-term storage, conservation and RW disposal facilities " held by STC No. 10 of the State Corporation "Rosatom" on April 11, 2014].

13. Osnovnyye sanitarnyye pravila obespecheniya radiatsionnoy bezopasnosti. SP 2.6.1.2612-10 (OSPORB99/2010): utverzhdeny postanovleniyem Glavnogo gosudarstvennogo sanitarnogo vracha Rossiyskoy Federatsii ot 26.04.2010 g. no. 40 (s izmeneniyami na 16.09.2013). [Basic sanitary rules for radiation safety. SP 2.6.1.2612-10 (OSPORB99/2010): approved by the Decree of the Chief State Sanitary Doctor of the Russian Federation on April 26, 2010 no. 40 (as amended on September 16, 2013)].

14. O vozmozhnosti i tselesoobraznosti korrektirovki predel'nykh norm soderzhaniya al'fa-izluchayushchikh nuklidov v tverdykh RAO (kompleksa 
tsementirovaniya), opredelennykh postanovleniyem Pravitel'stva Rossiyskoy Federatsii ot 19.10.2012 no.1069: Resheniye NTS no. 10 «Ekologicheskaya, yadernaya i radiatsionnaya bezopasnost'» Goskorporatsii «Rosatom» ot 28.04.2016 [On the possibility and reasonability of adjusting the regulatory limits on the content of alpha-emitting nuclides in solid radioactive waste (cementing complex) stipulated in the Government Resolution of the Russian Federation of October 19, 2012 no. 1069: Decision made by STC no. 10 "Ecological, nuclear and radiation safety" of the State Corporation Rosatom on April 28, 2016].

15. Aktual'nyye problemy obrashcheniya $\mathrm{s}$ VAO i SAO na FGUP «PO «Mayak» i FGUP «GKHK. Khod rabot po sozdaniyu PIL i PGZRO v Nizhnekanskom massive: Resheniye sovmestnogo zasedaniya NTS no.5 «Zamykayushchaya stadiya yadernogo toplivnogo tsikla» i NTS no. 10 «Ekologiya i radiatsionnaya bezopasnost'» Goskorporatsii «Rosatom» ot 16.10.2019. - Utv. predsedatelem NTS no. 5 Goskorporatsii «Rosatom» akad. RAN B. F. Myasoyedovym i predsedatelem NTS no. 10 Goskorporatsii «Rosatom» akad. RAN L. A. Bol'shovym [Current challenges in the management of HLW and ILW at FSUE PA Mayak and FSUE MCC. Progress in the development of a URL and a deep geological disposal facility for RW in the Nizhnekanskiy rock mass: Decision of a joint meeting held by STC no. 5 "Final stage of nuclear fuel cycle" and STC no. 10 "Ecology and radiation safety" of the State Atomic Energy Corporation ROSATOM on October 16, 2019. - Approved by the Chairman of the STC no. 5 of the State Atomic Energy Corporation Rosatom, Member of RAS B. F. Myasoedov and the Chairman of the STC no. 10 of the State Atomic Energy Corporation "Rosatom", Member of RAS L. A. Bolshov].

16. Ivanov E. A., Sharov D. A., Demyanenko M. V., Sharafutdinov R. B., Kuryndin A. V. O nekotorykh problemakh obrashcheniya $\mathrm{s}$ promyshlennymi otkhodami, soderzhashchimi tekhngogennyye radionuklidy [On certain issues in the management of industrial waste containing technogenic radionuclides]. Yadernaya i radiatsionnaya bezopasnost' - Nuclear and Radiation Safety, 2019, no. 3 (93), pp. 3-13.

17. Abramov A. A., Bolshov L. A., Gavrilov P. M., Dorofeev A. N., Igin I. M., Linge I. I., Mokrov Yu. G., Pechkurov A. V., Utkin S. S. Ob ideyakh rasshireniya sistemy obrashcheniya s RAO na promyshlennyye otkhody, soderzhashchiye tekhnogennyye radionuklidy [About the ideas on expanding the radioactive waste management system to embrace industrial waste containing technogenic radionuclides]. Radioaktivnyye otkhody - Radioactive waste, 2019, no. 4 (9), pp. 6-13.
18. Razvitiye normativnoy bazy po radiatsionnoy bezopasnosti: Resheniye NTS no. 10 «Ekologiya i radiatsionnaya bezopasnost'» Goskorporatsii «Rosatom» ot 17.12.2019. [Development of a regulatory framework for radiation safety: Decision of STC no. 10 "Ecology and Radiation Safety" of the State Atomic Energy Corporation Rosatom of December 17, 2019].

19. Dorogov V. I. K obsuzhdeniyu vneseniya izmeneniy v klyuchevyye normativnyye dokumenty po obrashcheniyu s RAO [To the discussion on introducing certain amendments to key regulations in radioactive waste management]. Radioaktivnyye otkhody Radioactive waste, 2020, no. 1 (10), pp. 113-114.

20. O provedenii pervichnoy registratsii radioaktivnykh otkhodov: Postanovleniye Pravitel'stva Rossiyskoy Federatsii ot 25.07.2012 no. 767 [On the primary registration of radioactive waste: Government Resolution of the Russian Federation of July 25, 2012 no. 767] Sobr. zakonodatel'stva Ros. Federatsii - Laws of the Russian Federation, 2012, no. 32, Art. 4554.

21. Linge I. I, Savkin M. N., Abalkina I. L. et al. Razvitiye podkhodov k obosnovaniyu otneseniya RAO k osobym RAO [Development of approaches to the justification of RW assignment to special RW category]. IBRAE Preprint No. IBRAE-2014-04. Moscow, Nuclear Safety Institute of RAS Publ., 2014. 29 p.

22. Abalkina I. L., Barchukov V. G., Bochkarev V. V., Vedernikova M. V., Dorogov V. I., Kochetkov O. A., Kryshev I. I., Linge I. I., Panchenko S. V., Savkin M. N., Utkin S. S. Nauchno-tekhnicheskoye posobiye po podgotovke obosnovyvayushchikh materialov dlya prinyatiya resheniya ob otnesenii radioaktivnykh otkhodov $k$ osobym radioaktivnym otkhodam [Scientific and technical manual on the development of substantiating materials for decision-making on radioactive waste assignment to the category of special radioactive waste]. Version 2.0. Moscow, 2014.

23. Abramov A. A., Savkin M. N., Vedernikova M. V., Linge I. I., Utkin S. S., Dorogov V. I., Kryshev I. I., Barchukov V. G., Kochetkov O. A., Kuryndina L. A. Metodicheskiye podkhody k obosnovaniyu otneseniya RAO k osobym RAO [Methodological approaches supporting the decision making on waste assignment to the category of special RW] In the book: Osobyye radioaktivnyye otkhody [Special Radioactive Waste]. Abramov A.A., Dorofeev A.N., Tyazhkorob Zh. V. et al. Moscow, 2015. Pp. 106-146.

24. $\mathrm{O}$ rabote po primeneniyu $\mathrm{v}$ organizatsiyakh otrasli «Nauchno-tekhnicheskogo posobiya po podgotovke obosnovyvayushchikh materialov dlya prinyatiya resheniya ob otnesenii radioaktivnykh otkhodov k osobym radioaktivnym otkhodam. Versiya 2.0: Resheniye sektsii no. 1 «Ekologicheskaya i radiatsionnaya bezopasnost' punktov dolgovremennogo khraneniya, konservatsii i zakhoroneniya RAO» 
NTS no. 10 Goskorporatsii «Rosatom» ot 26.05.2015. [On practical application of the Scientific and Technical Manual on the Development of Substantiating Materials Supporting the Decision-Making on Radioactive Waste Assignment to the Special Radioactive Waste Category" by organizations. Version 2.0: Decision of section no. 1 "Ecological and radiation safety of long-term storage, conservation and disposal facilities for radioactive waste" held by STC no. 10 of the State Corporation “Rosatom" of May 26, 2015].

25. Rezul'taty rabot po inventarizatsii YAROO i pervichnoy registratsii RAO, vklyuchaya otsenku snizheniya riska $v$ rezul'tate realizatsii FTSP YARB: Resheniye NTS no. 10 «Ekologicheskaya, yadernaya i radiatsionnaya bezopasnost'» ot 08.07.2015 [Inventory taking of nuclear and radiation hazardous facilities and primary RW registration: results of practical efforts including the assessment of risk reduction due to FTP NRS implementation: Decision of STC no. 10 "Ecological, nuclear and radiation safety" of July 8, 2015].

26. O khode proyektirovaniya i osnovnykh proyektnykh resheniyakh po sooruzheniyu punkta glubinnogo zakhoroneniya radioaktivnykh otkhodov $\mathrm{v}$ gornykh porodakh Nizhnekanskogo massiva: Resheniye NTS no. 10 «Ekologicheskaya, yadernaya i radiatsionnaya bezopasnost'» Goskorporatsii «Rosatom» ot 05.09.2013 [On the design progress and basic design decisions for the construction of a deep radioactive waste disposal facility in the of the Nizhnekanskiy rock mass: Decision of STC no. 10 "Ecological, nuclear and radiation safety" of the State Atomic Energy Corporation "Rosatom", September 5, 2013].

27. Programma provedeniya issledovaniy v podzemnoy issledovatel'skoy laboratorii (PIL) na NizhneKanskom massive dlya podtverzhdeniya proyektnykh parametrov bezopasnosti podzemnogo zakhoroneniya RAO klassov 1 i 2: Resheniye sektsii no. 1 «Ekologicheskaya i radiatsionnaya bezopasnost' punktov dolgovremennogo khraneniya, konservatsii i zakhoroneniya RAO» NTS no. 10 Goskorporatsii «Rosatom» ot 16.03.2016 [R\&D program in the Nizhnekansk rock mass underground research laboratory (URL) to confirm the design parameters for the safe underground disposal of class 1 and 2 RW: Decision of section no. 1 "Ecological and radiation safety of long-term storage, conservation and disposal facilities for radioactive waste" held by STC no. 10 of the State Corporation "Rosatom" on March 16, 2016].

28. Bezopasnost' zakhoroneniya RAO: Resheniye NTS no. 10 «Ekologicheskaya, yadernaya i radiatsionnaya bezopasnost'» Goskorporatsii «Rosatom» ot 13.12.2016. Prilozheniye: Perechen' pervoocherednykh issledovaniy po obosnovaniyu dolgovremennoy bezopasnosti i ustraneniyu zamechaniy ekspertiz na 2017-2019 gg. [Safety of RW disposal: Decision of
STC no. 10 "Ecological, nuclear and radiation safety" of the State Atomic Energy Corporation "Rosatom" of December 13, 2016. Appendix: List of priority studies on long-term safety demonstration and on addressing the expert comments in 2017-2019].

29. Dorofeev A. N., Bolshov L. A., Linge I. I., Utkin S. S., Savelyeva E. A. Strategicheskiy master-plan issledovaniy $\mathrm{v}$ obosnovaniye bezopasnosti sooruzheniya, ekspluatatsii i zakrytiya punkta glubinnogo zakhoroneniya radioaktivnykh otkhodov [Strategic master plan for research demonstrating the safety of deep radioactive waste disposal facility construction, operation and closure]. Radioaktivnyye otkhodyRadioactive Waste, 2017, no. 1, pp. 32-41.

30. Rassmotreniye bazovykh proyektnykh i tekhnicheskikh resheniy po podzemnoy issledovatel'skoy laboratorii i punktu glubinnogo zakhoroneniya RAO (Nizhnekanskiy massiv): Resheniye sovmestnogo zasedaniya NTS no. 5 «Zamykayushchaya stadiya yadernogo toplivnogo tsikla» i NTS no. 10 «Ekologiya i radiatsionnaya bezopasnost'» Goskorporatsii «Rosatom» ot 27.10.2017. - Utv. predsedatelem NTS no. 5 Goskorporatsii «Rosatom» akad. RAN B. F. Myasoyedovym i predsedatelem NTS no. 10 Goskorporatsii «Rosatom» akad. RAN L. A. Bol'shovym [Overview of basic design and technical solutions for an underground research laboratory and RW deep disposal facility (Nizhnekanskiy Massif): Decision of a joint meeting held by STC no. 5 "Final stage of the nuclear fuel cycle" and STC no. 10 "Ecology and Radiation Safety" of "Rosatom" State Corporation of October 27, 2017. - Approved by the Chairman of STC no. 5 of the State Atomic Energy Corporation Rosatom, Member of RAS B. F. Myasoedov and Chairman of the STC no. 10 of the State Atomic Energy Corporation "Rosatom", Member of RAS L. A. Bolshov].

31. Strategii sozdaniya punkta glubinnogo zakhoroneniya radioaktivnykh otkhodov. Utv. general'nym direktorom Goskorporatsii «Rosatom» A. Ye. Likhachevym 28.04.2018 [Strategies for the development of deep radioactive waste disposal facilities. Approved by Director General of the State Corporation "Rosatom" A. E. Likhachev on April 28, 2018].

32. Realizatsiya «Strategii sozdaniya punkta glubinnogo zakhoroneniya radioaktivnykh otkhodov»: Resheniye sektsii no. 1 «Ekologicheskaya i radiatsionnaya bezopasnost' punktov dolgovremennogo khraneniya, konservatsii i zakhoroneniya RAO» NTS no. 10 Goskorporatsii «Rosatom» ot 9.07.2018. [Implementation of the "Strategy for the development of a deep radioactive waste disposal facility": Decision of Section no. 1 "Ecological and radiation safety of long-term storage, conservation and disposal facilities for radioactive waste" held by STC no. 10 of the State Corporation “Rosatom” on July 9, 2018]. 
33. Oblik PIL, sozdavayemoy v Nizhnekanskom massive, i sostav planiruyemykh eksperimentov, napravlennykh na polucheniye neobkhodimykh dannykh dlya obosnovaniya dolgovremennoy bezopasnosti PGZRO: Resheniye sektsii no. 1 «Ekologicheskaya i radiatsionnaya bezopasnost' punktov dolgovremennogo khraneniya, konservatsii i zakhoroneniya RAO» NTS no. 10 Goskorporatsii «Rosatom» ot 10.10.2018 [Conceptual designs of the URL developed in the Nizhnekanskiy rock mass and R\&Ds planned to obtain the data required to demonstrate the long-term safety of the deep disposal facility: Decision of section no. 1 "Ecological and radiation safety of longterm storage, conservation and disposal facilities for RW" held by STC no. 10 of the State Corporation "Rosatom" on October 10, 2018].

34. O programme rabot po ustraneniyu zamechaniy Missii MAGATE po otsenke sootvetstviya rossiyskoy tekhnologii podzemnogo zakhoroneniya ZHRO trebovaniyam po bezopasnosti MAGATE i khode rabot po yeyo realizatsii: Resheniye NTS no. 10 «Ekologicheskaya, yadernaya i radiatsionnaya bezopasnost'» Goskorporatsii «Rosatom» ot 17.07.2014 [On the work program addressing the comments of the IAEA Peer Review Mission on the compliance of the Russian underground LRW injection technology with IAEA safety requirements and the progress in its implementation: Decision of STC no. 10 "Ecological, Nuclear and Radiation Safety" of the State Atomic Energy Corporation "Rosatom” of July 17, 2014].

35. O sootvetstvii sozdavayemogo punkta zakhoroneniya radioaktivnykh otkhodov 3 i 4 klassa (na baze khranilishcha TRO NPK FGUP «Radon») analogichnym uzhe postroyennym, $\mathrm{v}$ tom chisle za rubezhom, s tochki zreniya effektivnosti i ekologicheskoy bezopasnosti: Resheniye sektsii no. 1 «Ekologicheskaya i radiatsionnaya bezopasnost' punktov dolgovremennogo khraneniya, konservatsii i zakhoroneniya RAO» NTS no. 10 Goskorporatsii «Rosatom» ot 25.05.2015 [On the conformity of the developed disposal facility for RW class 3 and 4 (on the basis of a SRW storage facility run by SPC FSUE
Radon) with already constructed ones, including those constructed abroad, in terms of its efficiency and environmental safety: Decision of section no. 1 "Ecological and radiation safety of long-term storage, conservation and disposal facilities for RW " held by STC no. 10 of the State Corporation "Rosatom" on May 25, 2015].

36. Voprosy obosnovaniya dolgosrochnoy bezopasnosti pripoverkhnostnykh punktov zakhoroneniya TRO 3 i 4 klassov: Resheniye sektsii no. 1 «Ekologicheskaya i radiatsionnaya bezopasnost' punktov dolgovremennogo khraneniya, konservatsii i zakhoroneniya RAO» NTS no. 10 Goskorporatsii «Rosatom» ot 12.04.2019 [On long-term safety demonstration for SRW class 3 and 4 near-surface disposal facilities: Decision of section no. 1 "Ecological and radiation safety of long-term storage, conservation and disposal facilities for radioactive waste" held by STC no. 10 of the State Corporation "Rosatom" on April 12, 2019].

37. O razvitii programmnykh kompleksov geomigratsionnogo i geofil'tratsionnogo modelirovaniya: Resheniye NTS no. 10 «Ekologicheskaya, yadernaya i radiatsionnaya bezopasnost'» Goskorporatsii «Rosatom» ot 29.10.2015 [On the development of software systems simulating geomigration and geofiltration processes: Decision of STC no. 10 "Ecological, nuclear and radiation safety" of the State Atomic Energy Corporation ROSATOM of October 29, 2015]. 38. Tekushcheye sostoyaniye i strategicheskiye potrebnosti sistemy raschetnykh kodov dlya zadach obosnovaniya radiatsionnoy i ekologicheskoy bezopasnosti ob"yektov yadernogo naslediya i punktov zakhoroneniya radioaktivnykh otkhodov: Resheniye NTS no. 10 «Ekologiya i radiatsionnaya bezopasnost'» Goskorporatsii «Rosatom» ot 24.10.2018 [Current status and strategic needs for the software code system addressing the tasks of radiation and environmental safety demonstration for nuclear legacy facilities and radioactive waste disposal facilities: Decision of STC No. 10 "Ecology and Radiation Safety" of the State Atomic Energy Corporation Rosatom of October 24, 2018].

\section{Information about the authors}

Utkin Sergey Sergeevich, Doctor of Technical Sciences, Head of Department, Nuclear Safety Institute of the Russian Academy of Sciences (52, Bolshaya Tulskaya St., Moscow, 115191, Russia), e-mail: uss@ibrae.ac.ru.

Dorogov Viktor Ilyich, PhD, Head of Office, Nuclear Safety Institute of the Russian Academy of Sciences (52, Bolshaya Tulskaya St., Moscow, 115191, Russia), e-mail: vid@ibrae.ac.ru.

Dorofeev Aleksandr Nikolaevich, PhD, Head of the Project Office on the Development of a Unified Radioactive Waste Management System, State Corporation “Rosatom” (24, Bolshaya Ordynka St., Moscow, 119017, Russia), e-mail: ANDorofeev@rosatom.ru.

\section{Bibliographic description}

Utkin S. S., Dorogov V. I., Dorofeev A. N. RW Disposal in Russia: Analysis of Key Safety Issues and Boosting their Solution at Scientific and Technical Councils of the State Corporation "Rosatom". Radioactive Waste, 2020, no 2 (11), pp. 36-55. (In Russian). DOI: 1025283 / 2587-9707-2020-2-36-55. 